\title{
Pengaruh Pendekatan Open Ended Problems terhadap Kemampuan Berpikir Kreatif Matematika Siswa pada Materi Peluang di Kelas XI SMA Negeri 1 Rantau Utara
}

\section{The Effect of Open Ended Problems Approach on Students' Creative Mathematical Thinking Ability on Opportunities in Class XI of SMA Negeri 1 Rantau Utara}

\author{
Sri Munarsih ${ }^{1}$, Lily Rohanita Hasibuan ${ }^{2}$, Irmayanti ${ }^{3}$ \\ Mahasiswa Program Studi Pendidikan Matematika STKIP Labuhanbatu \\ ${ }^{2}$ Dosen Program Studi Pendidikan Matematika STKIP Labuhanbatu \\ ${ }^{3}$ osen Program Studi Pendidikan Matematika STKIP Labuhanbatu \\ STKIP Labuhanbatu,JIn. SM. Raja No. 126A, KM, 3.5 Aek Tapa, Rantauprapat Email: srimunarsih94@gmail.com
}

\begin{abstract}
Abstrak
Penelitian ini mengkaji pembelajaran dengan menggunakan pendekatan open ended Problems terhadap kemampuan berpikir kreatif matematika siswa pada materi peluang. Tujuan penelitian ini adalah (1)untuk mendeskripsikan proses pembelajaran matematika dengan menggunakan pendekatan Open Ended Problems, (2)mengetahui seberapa besar pengaruh pendekatan Open Ended Problems terhadap kemampuan berpikir kreatif matematika siswa. Populasi dalam penelitian ini adalah seluruh siswa kelas XI SMA Negeri 1 Rantau Utara sedangkan sampel yang diambil adalah kelas XI IPA2 dan XI IPA4 Tahun Pembelajaran 2017/2018 yang masing-masing kelas sebanyak 40 siswa.Instrumen penelitian ini menggunakan tes berpikir kreatif matematika berbentuk 5 soal tes uraian dengan mengacu pada indikator kemampuan berpikir kreatif matematika dari Munandar. Hasil penelitian menunjukkan nilai rata-rata posttest kelas kontrol 71.50 dengan Standar Deviasi 9.001, nilai rata-rata posttest kelas eksperimen 75.75 dengan Standar Deviasi 8.811. Pada hasil uji t diperoleh nilai thitung sebesar 2.224 dan tabel sebesar 1.683, maka $2.224>1.683$ dengan tingkat signifikan $0.036<0.05$ maka $\mathrm{H}_{\circ}$ ditolak dan $\mathrm{H}_{\mathrm{a}}$ diterima. Maka, terdapat pengaruh pendekatan Open Ended Problems terhadap kemampuan berpikir kreatif matematika siswa. Kesimpulan penelitian ini adalah terdapat pengaruh pendekatan Open Ended Problems terhadap kemampuan berpikir kreatif matematika siswa dan proses jawaban siswa sebelum proses pembelajaran rendah menjadi meningkat setelah diberikan pembelajaran dengan pendekatan Open Ended Problems dan hasilnya lebih baik dari pada siswa dengan pembelajaran konvensional. Pendekatan Open Ended Problems berpengaruh positif terhadap kemampuan berpikir kreatif matematika siswa terutama pada aspek kelancaran dan keluwesan berpikir.
\end{abstract}

\section{Kata Kunci: Pendekatan Open Ended Problems, Berpikir Kreatif Matematika}

\begin{abstract}
This study examines learning by using open-ended approach to the mathematical creative thinking abilities of students on the opportunity lesson. The purpose of this study is (1)to train the students' ability to think creatively in a matter of figures with flat sides, (2) know how much influence the open-ended approach to the mathematical creative thinking abilities. Population studied are the students of class XI IPA in SMA Negeri 1 Rantau Utara. Subjects studied are the students of class XI IPA2 and XI IPA4 is 40 students. The research instrument using mathematical creative thinking test made by researchers with reference to indicators of mathematical creative thinking abilities of Munandar. The research result has shown of learning has got posttest control mean value $=71.50$ with standart deviation 9.001, posttest eksperiment mean value $=75.75$ with standart deviation 8.811. For the $t$ test by comparing between the $t_{\text {count }}>t_{\text {table }}$ or $2.224>1.683$ with significant value $0.036<0.05$, so $\mathrm{H}_{a}$ was received. So, there are Effect of Open-Ended Approach Ability Against Students Creative Thinking Mathematically. The conclusion of this study is there's The Effect of OpenEnded Approach Ability Against Students Creative Thinking Mathematically on the Opportunity Lesson for Grade XI Students of SMA Negeri 1 Rantau Utara. And the ability to think creatively mathematically lower the learning process of students before being given increased after learning with open-ended approach and the results are better than the students with the conventional approach. Open ended approach a positive effect on students' ability to think creatively, especially on the mathematical aspects of fluency and flexibility of thinking.
\end{abstract}

\section{Key Words : Open Ended Approach, Creative Thinking Mathematically}




\section{Pendahuluan}

Salah satu usaha untuk mampu bersaing dalam menghadapi tantangan masa depan yang selalu berubah dan semakin ketat adalah melalui peningkatan kualitas pendidikan. Peningkatan ini diperlukan disetiap bidang pendidikan, termasuk dalam bidang matematika.Matematika merupakan salah bidang pendidikan yang bertujuan mengembangkan kemampuan berpikir secara logis, analitis, sistematik, kritis dan kreatif untuk menyelesaikan masalah yang ada[1]. Tujuan tersebut dapat tercapai bila pembelajaran matematika menekankan pada aspek peningkatan kemampuan berpikir tingkat tinggi yang mengharuskan siswa memanipulasi informasi dan ide dalam cara tertentu sehingga menghasilkan pengertian dan implikasi baru.

Kemampuan berpikir tingkat tinggi harus mulai dikembangkan oleh siswa sejak dini. Karena dengan memiliki kemampuan berpikir tingkat tinggi yang baik, siswa dapat dengan mudah mencari informasi baru dan mengaitkannya dengan informasi yang telah dimiliki. Selanjutnya, mengolah informasi tersebut untuk mengembangkan ide-ide baru dan memilih strategi penyelesaian yang tepat untuk memecahkan masalah yang sedang dihadapi. Ketika siswa mampu menyelesaikan masalah dengan kemampuan mereka sendiri, hal ini akan berdampak positif terhadap penilaian diri.

Salah satu kemampuan berpikir tingkat tinggi adalah kemampuan berpikir kreatif. Kemampuan ini merupakan aspek penting dalam pengembangan bakat matematika. Peningkatan kemampuan berpikir kreatif siswa dapat memberikan kesempatan bagi perkembangan potensi mereka yang lain seperti minat dan bakat. Dengan kemampuan berpikir kreatif yang baik, siswa akan mampu menghasilkan ide-ide kreatif dalam menyelesaikan masalah.

Berpikir kreatif matematis merujuk pada kemampuan untuk menghasilkan solusi bervariasi yang bersifat baru terhadap masalah matematika yang bersifat terbuka. Munandar mengemukakan lima unsur berpikir kreatif matematika yaitu:(1) Kelancaran (membuat berbagai ide/gagasan); (2) Kelenturan (kelihaian memandang ke depan dengan mudah); (3) Keaslian (menyusun sesuatu yang baru);(4) Elaborasi (membangun sesuatu dari ide-ide lainnya); (5)Evaluatif (menilai serta melaksanakan ide) [2].

Berdasarkan hasil wawancara pada Hari Selasa 25 april 2017 dengan Bapak Rahmat Syahputra Tanjung,S.Pd sebagai salah satu guru mata pelajaran matematika di sekolah SMA Negeri 1 Rantau Utara. Masalah yang ditemukan dalam belajar matematika antara lain adalah kurangnya respon dan semangat sebahagian siswa dalam mengikuti pembelajaran di kelas dan cenderung pasif. Dalam proses pembelajaran lebih dominan menggunakan metode ceramah atau konvensional yang berpusat pada guru, tetapi pernah juga menerapkan metode diskusi atau kelompok, serta menggunakan model pembelajaraan kooperatif seperti model CTL namun hasilnya kurang maksimal. Bapak Rahmat Syahputra Tanjung,S.Pd juga mengatakan bahwa juga ditemukan masalah rendahnya kemampuan berpikir kreatif matematis sebahagian siswa terlihat dari siswa yang masih bingung serta tidak dapat mengartikan soal-soal berbentuk cerita. Berikut ini adalah salah satu proses jawaban siswa dengan kemampuan berpikir kreatif matematika siswa.

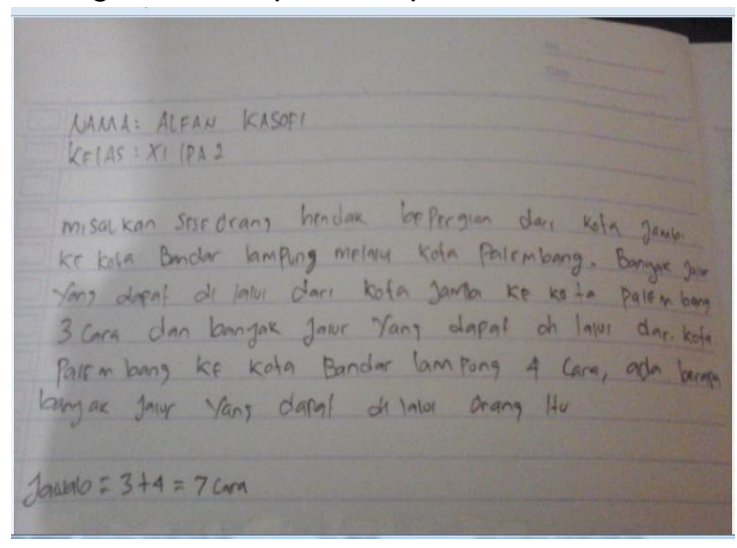

Gambar 1 Proses jawaban siswa dengan jawaban salah dan proses jawaban siswa tidak lengkap.

Dalam mengembangkan kemampuan berpikir kreatif matematika siswa Guru harus menerapkan pendekatan atau metode pembelajaran yang dapat memfasilitasi perkembangan kemampuan tersebut secara maksimal. Oleh karena itu, diperlukan metode pembelajaran serta pendekatan yang dapat memberi ruang bagi siswa untuk mengeksplor potensi mereka untuk mengembangkan kemampuan berpikir kreatif. 
Kemampuan tersebut dapat ditingkatkan melalui berbagai pendekatan dan metode pembelajaran, salah satunya dengan memberikan open-ended problems atau masalah terbuka. Pemberian open-ended problems pada siswa bertujuan untuk mengetahui bagaimana cara siswa untuk mendapatkan jawaban. Open ended problems merupakan masalah dengan jawaban atau strategi penyelesaian yang bervariasi. Pengggunaan open ended problems dapat memberikan kebebasan bagi siswa untuk mengembangkan ide-ide dan mengeksplor kemampuan mereka yaitu kemampuan berpikir kreatif siswa dalam pembelajaran matematika. Selain itu, open-ended problems juga merupakan masalah non rutin dengan banyak strategi penyelesaian dan jawaban yang bervariasi. Siswa diberi kebebasan untuk memilih strategi sendiri yang akan menghasilkan beragam jawaban atau mencoba berbagai strategi untuk mencari satu jawaban.

Sesuai dengan Peraturan Menteri Pendidikan Nasional Nomor 65 Tahun 2013 Tentang Standar Proses menetapkan adanya perubahan dari pembelajaran yang menekankan jawaban tunggal menuju pembelajaran dengan jawaban yang kebenarannya multi dimensi. Hal ini mengakibatkan permasalahan open ended dapat digunakan dalam pembelajaran matematika untuk mengetahui kemampuan berfikir kreatif dan skill matematika siswa secara cepat.

\section{Metode Penelitian}

Penelitian ini adalah penelitian quasi eksperimen. Penelitian ini bertujuan untuk mengetahui pengaruh pendekatan Open Ended Problems terhadap kemampuan berpikir kreatif matematika siswa. Lokasi penelitian berada di SMA Negeri 1 Rantau Utara Kecamatan Rantau Utara Kabupaten Labuhanbatu. Adapun waktu penelitian ini dilaksanakan pada semester I tahun Pembelajaran 2017/2018. Desain perlakuan dapat dilihat pada Tabel 1.

Tabel 1 Pretest Posttest Control Group Design

\begin{tabular}{|c|c|c|c|}
\hline Kelas & $\begin{array}{c}\text { Tes Awal } \\
\text { (Pretest) }\end{array}$ & Perlakuan & $\begin{array}{c}\text { Tes Akhir } \\
\text { (Posttest) }\end{array}$ \\
\hline Eksperimen & Y1 & $\begin{array}{c}\text { Pendekatan Open } \\
\text { Ended Problems }\end{array}$ & Y2 \\
\hline Kontrol & Y1 & Konvensional & Y2 \\
\hline
\end{tabular}

Keterangan :

$Y_{1}$ : Tes kemampuan sebelum diberikan pendekatan pembelajaran

$\mathrm{Y}_{2}$ : Tes kemampuan sebelum diberikan pendekatan pembelajaran

\section{Hasil Penelitian dan Pembahasan}

\section{Hasil Penelitian \\ Deskripsi Pretest Kelas Kontrol dan Eksperimen}

Distribusi frekuensi nilai-nilai pretest 40 siswa kelas kontrol dan kelas eksperimen dijabarkan dalam tabel 2 dan 3 berikut:

Tabel 2 Distribusi Frekuensi Nilai Pretest Kelas Kontrol

\begin{tabular}{|c|c|c|}
\hline No & $\begin{array}{c}\text { Interval } \\
\text { Nilai }\end{array}$ & Frekuensi \\
\hline 1 & $35-41$ & 7 \\
\hline 2 & $42-48$ & 9 \\
\hline 3 & $49-55$ & 17 \\
\hline 4 & $56-62$ & 4 \\
\hline 5 & $63-69$ & 2 \\
\hline 6 & $70-75$ & 1 \\
\hline \multicolumn{2}{|c|}{ Jumlah } & $\mathbf{4 0}$ \\
\hline
\end{tabular}


Berdasarkan tabel 4 di atas, terlihat bahwa siswa yang mendapatkan nilai terendah yaitu nilai $35-41$ sebanyak 7 siswa, dan siswa yang mendapatkan nilai tertinggi yaitu nilai $70-75$ hanya 1 siswa. Dengan nilai rata-rata 50.13 dan standar deviasi 8.951 .

Histogram

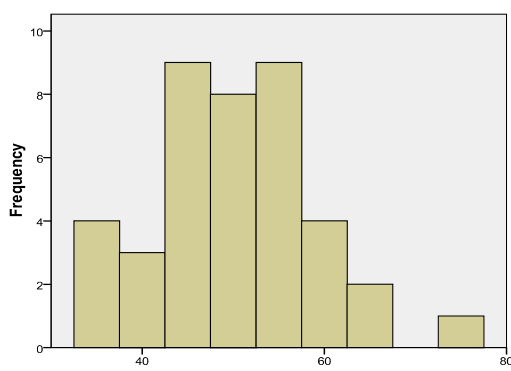

NILAPRETESTKONTROL

\section{Gambar 2 Diagram DistribusiFrekuensi Nilai Pretest Kelas Kontrol}

Ket : Nilai 45 dan 55 adalah nilai yang paling banyak frekuensinya.

Tabel 3 Distribusi Frekuensi Nilai Pretest Kelas Eksperimen

\begin{tabular}{|c|c|c|}
\hline No & $\begin{array}{c}\text { Interval } \\
\text { Nilai }\end{array}$ & Frekuensi \\
\hline 1 & $30-37$ & 6 \\
\hline 2 & $38-45$ & 8 \\
\hline 3 & $46-53$ & 7 \\
\hline 4 & $54-61$ & 15 \\
\hline 5 & $62-69$ & 1 \\
\hline 6 & $70-75$ & 3 \\
\hline \multicolumn{2}{|c|}{ Jumlah } & $\mathbf{4 0}$ \\
\hline
\end{tabular}

Berdasarkan tabel 5 di atas, terlihat bahwa siswa yang mendapatkan nilai terendah yaitu nilai $30-47$ sebanyak 6 siswa, dan siswa yang mendapatkan nilai tertinggi yaitu nilai $70-75$ sebanyak 3 siswa. Dengan nilai rata-rata 51.50 dan standar deviasi 11.22 .

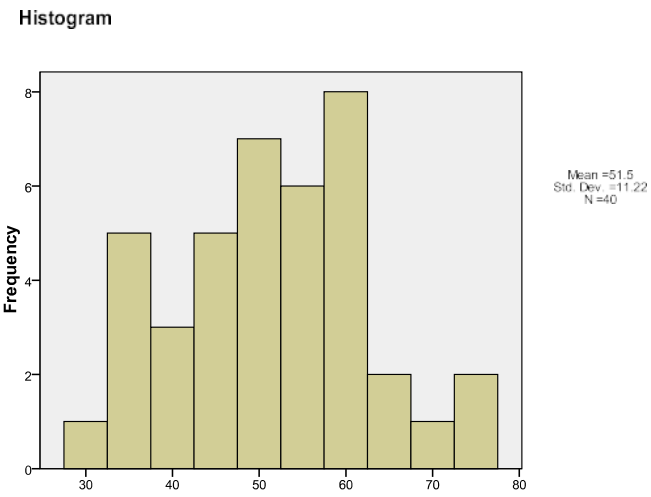

NILAPRETESTEKSPERIMEN

\section{Gambar 3 Diagram DistribusiFrekuensi Nilai Pretest Kelas Eksperimen}

Ket : Nilai 60 adalah nilai yang paling banyak frekuensinya.

Analisis deskriptif digunakan untuk menggambarkan nilai awal kedua kelas sebelum diberi perlakuan. Tabel 6 menunjukkan hasil analisis deskriptif yang diperoleh dengan menggunakan program SPSS 17.00. 
Tabel 4 Hasil Analisis Deskriptif Pretest

\begin{tabular}{|l|c|c|c|c|c|}
\hline Kelas & N & Minimum & Maximum & Mean & $\begin{array}{l}\text { Standar } \\
\text { Deviasi }\end{array}$ \\
\hline Eksperimen & 40 & 30 & 75 & 51.50 & 11.22 \\
\hline Kontrol & 40 & 35 & 75 & 50.13 & 8.951 \\
\hline
\end{tabular}

Berdasarkan tabel 6 di atas, dapat disimpulkan bahwa kelas eksperimen mempunyai nilai rata-rata 51.50 dengan nilai minimum 30 dan nilai maksimum 75 serta standar deviasi 11.22. Kelas kontrol mempunyai nilai rata-rata 50.13 dengan nilai minimum 35 dan nilai maksimum 75 serta standar deviasi 8.951. Hal ini menunjukkan bahwa tidak terdapat perbedaan rata-rata yang cukup besar antara kelas eksperimen dan kelas kontrol.

\section{Deskripsi Posttest Kelas Kontrol dan Eksperimen}

Distribusi frekuensi nilai-nilai posttest 40 siswa kelas kontrol dan kelas eksperimen dijabarkan dalam tabel 5 dan 6 berikut:

Tabel 5 Distribusi Frekuensi Nilai Posttest Ke
\begin{tabular}{|c|c|c|}
\hline No & $\begin{array}{c}\text { Interval } \\
\text { Nilai }\end{array}$ & Frekuensi \\
\hline 1 & $50-56$ & 3 \\
\hline 2 & $57-63$ & 2 \\
\hline 3 & $64-70$ & 16 \\
\hline 4 & $71-77$ & 8 \\
\hline 5 & $78-84$ & 8 \\
\hline 6 & $85-90$ & 3 \\
\hline Jumlah & 40 \\
\hline
\end{tabular}

Berdasarkan tabel 7 di atas, terlihat bahwa siswa yang mendapatkan nilai terendah yaitu nilai 50-56 sebanyak 3 siswa, dan siswa yang mendapatkan nilai tertinggi yaitu nilai 85 - 90 sebanyak 3 siswa. Dengan nilai rata-rata 71.50 dan standar deviasi 9.001.

Histogram

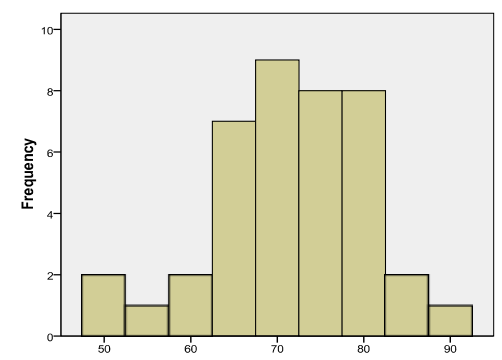

NILAPOSTKONTROL

Gambar 4 Diagram Batang Distribusi Frekuensi Nilai Posttest Kelas Kontrol

Ket : Nilai 70 adalah nilai yang paling banyak frekuensinya. 
Tabel 6 Distribusi Frekuensi Nilai Posttest Kelas Eksperimen

\begin{tabular}{|c|c|c|}
\hline No & $\begin{array}{c}\text { Interval } \\
\text { Nilai }\end{array}$ & Frekuensi \\
\hline 1 & $60-65$ & 7 \\
\hline 2 & $66-71$ & 7 \\
\hline 3 & $72-77$ & 8 \\
\hline 4 & $78-83$ & 9 \\
\hline 5 & $84-89$ & 6 \\
\hline 6 & $90-95$ & 3 \\
\hline \multicolumn{2}{|c|}{ Jumlah } & $\mathbf{4 0}$ \\
\hline
\end{tabular}

Berdasarkan tabel 6 di atas, terlihat bahwa siswa yang mendapatkan nilai terendah yaitu nilai $60-65$ sebanyak 7 siswa, dan siswa yang mendapatkan nilai tertinggi yaitu nilai 90 - 95 sebanyak 3 siswa. Dengan nilai rata-rata 75.75 dan standar deviasi 8.811 .

Histogram

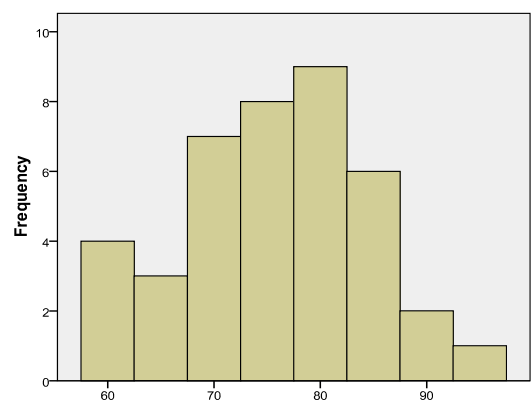

NILAPOSTEKSPERIMEN

Gambar 5 Diagram DistribusiFrekuensi Nilai Posttest Kelas Eksperimen

Ket : Nilai 80 adalah nilai yang paling banyak frekuensinya.

Analisis deskriptif digunakan untuk menggambarkan nilai akhir kedua kelas setelah diberi perlakuan. Tabel 6 menunjukkan hasil analisis deskriptif yang diperoleh dengan menggunakan program SPSS 17.00.

Tabel 6 Hasil Analisis Deskriptif Posttest

\begin{tabular}{|l|l|l|l|l|l|}
\hline Kelas & N & Minimum & Maximum & Mean & $\begin{array}{l}\text { Standar } \\
\text { Deviasi }\end{array}$ \\
\hline Eksperimen & 40 & 60 & 95 & 75.75 & 8.811 \\
\hline Kontrol & 40 & 50 & 90 & 71.50 & 9.001 \\
\hline
\end{tabular}

Berdasarkan tabel diatas, dapat disimpulkan bahwa kelas eksperimen mempunyai nilai rata-rata 75.75 dengan nilai minimum 60 dan nilai maksimum 95 dengan standar deviasi 8.811. Kelas kontrol mempunyai nilai rata-rata 71.50 dengan nilai minimum 50 dan nilai maksimum 90 dengan standar deviasi 9.001 . Hal ini menunjukkan bahwa terdapat perbedaan rata-rata antara kelas eksperimen dan kelas kontrol.

Berdasarkan perhitungan uji normalitas untuk nilai pretest diperoleh nilai sig kelas eksperimen $>$ taraf $\operatorname{sig}(\alpha=0,05)$ yaitu $0.200>0.05$ dan nilai sig kelas kontrol $>$ taraf $\operatorname{sig}(\alpha=0,05)$ yaitu $0.170>0.05$. sedangkan untuk nilai posttest diperoleh nilai sig kelas eksperimen $>$ taraf $\operatorname{sig}(\alpha=0,05)$ yaitu $0.063>0.05$ dan nilai sig 
kelas kontrol $>$ taraf $\operatorname{sig}(\alpha=0,05)$ yaitu $0.069>0.05$. Sehingga dapat disimpulkan bahwa nilai pretest dan posttest kedua kelas berdistribusi normal.

Berdasarkan perhitungan uji homogenitas untuk pretest didapatkan nilai $\operatorname{sig}>$ taraf $\operatorname{sig}(\alpha=0,05)$ yaitu $0.463>0.05$ dan untuk posttest didapatkan nilai $\operatorname{sig}>$ taraf $\operatorname{sig}(\alpha=0,05)$ yaitu $0.092>0.05$, sehingga nilai kedua kelas mempunyai varian yang sama atau homogen.

Berdasarkan uji hipotesis dengan menggunakan uji t diperoleh nilai sig < taraf $\operatorname{sig}(\alpha=0,05)$ yaitu 0.036 $<0.05$ dan thitung > tabel yaitu $2.224>1.683$ sehingga kemampuan berpikir kreatif matematika kelas eksperimen lebih besar dari kelas kontrol. Kesimpulan Ho ditolak, yang artinya terdapat pengaruh pendekatan Open Ended Problems terhadap kemampuan berpikir kreatif matematika siswa di kelas XI SMA Negeri 1 Rantau Utara.

\section{Deskripsi Proses Jawaban Siswa Menggunakan Pendekatan Open Ended Problems}

\section{Proses Jawaban Siswa saat Pretest}

Berikut ini merupakan proses jawaban siswa pada kelas eksperimen sebanyak 40 siswa sebelum diberi perlakuan dinyatakan bahwa lebih banyak siswa yang kurang mampu menyelesaikan soal dengan jawaban kurang lengkap dan salah.

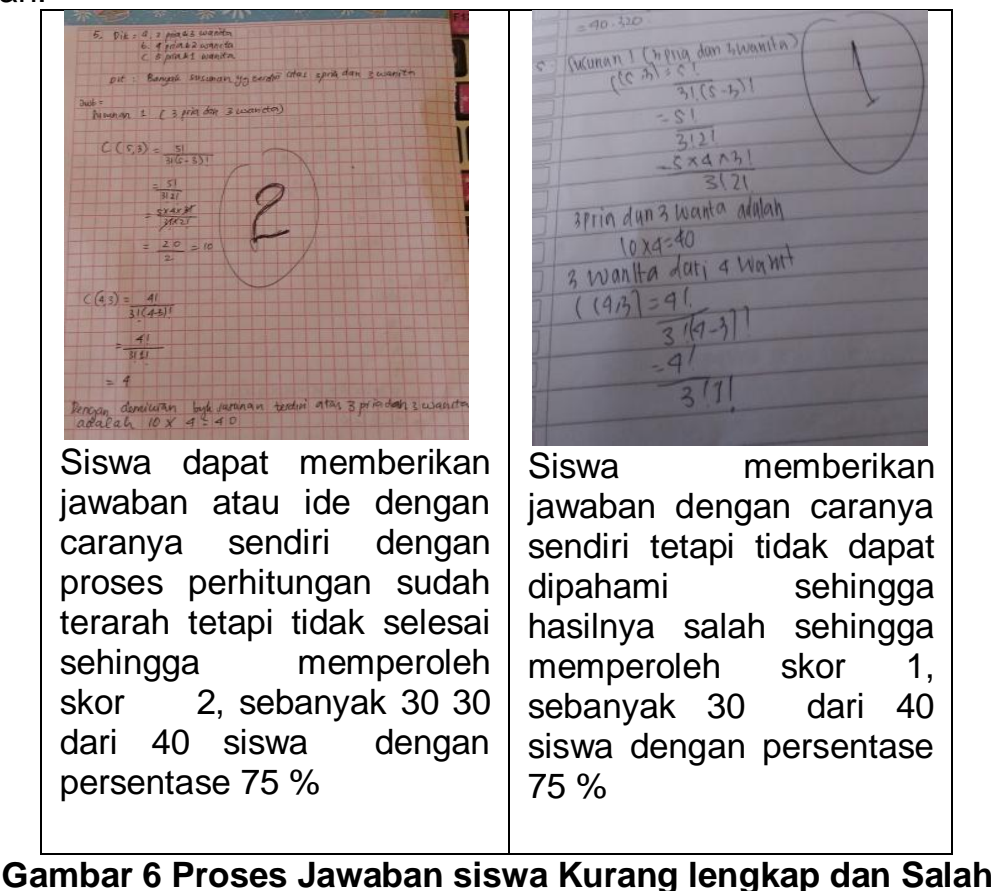

\section{Proses Jawaban Siswa saat Posttest}

Berikut ini merupakan proses jawaban siswa pada kelas eksperimen sebanyak 40 siswa setelah diberi perlakuan dengan menggunakan pendekatan Open Ended Problems dinyatakan bahwa lebih banyak siswa yang mampu menyelesaikan soal atau menjawab soal dengan baik, jelas, lengkap dan benar. Sehingga dapat dinyatakan bahwa pembelajaran dengan menggunakan pendekatan Open Ended Problems dapat meningkatkan kemampuan berpikir kreatif matematika siswa pada materi peluang, seperti yang ditunjukkan proses jawaban siswa sebagai berikut: 


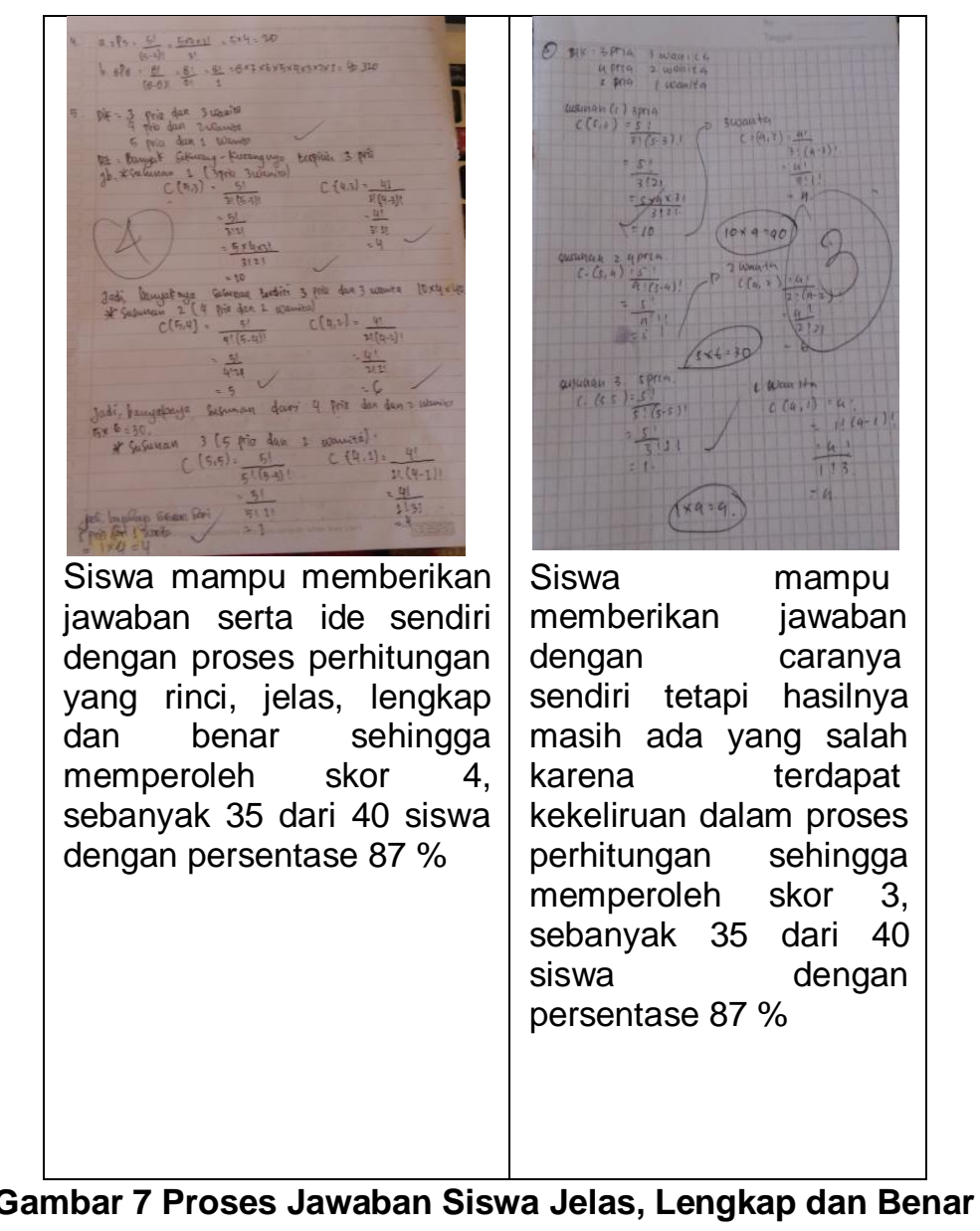

\section{Pembahasan Penelitian}

Penelitian ini telah dilaksanakan di kelas XI SMA Negeri 1 Rantau Utara Tahun Pembelajaran 2017/2018 dengan menerapkan pendekatan pembelajran Open Ended Problems diperoleh data hasil penelitian, yaitu data hasil tes kemampuan berpikir kreatif matematika siswa pada materi peluang, dimaksudkan untuk mencapai tujuan penelitian ini. Tujuan penelitian ini adalah untuk mengetahui pengaruh pendekatan Open Ended Problems terhadap kemampuan berpikir kreatif matematika siswa dan proses jawaban siswa dengan Pendekatan Open Ended Problems terhadap kemampuan berpikir kreatif matematika siswa pada materi peluang di kelas XI SMA Negeri 1 Rantau Utara dan melihat bagaimana proses jawaban siswa dalam menyelesaikan soal uraian kemampuan berpikir kreatif matematika pada materi peluang. Populasi dalam penelitian ini adalah seluruh siswa kelas XI SMA Negeri 1 Rantau Utara, dan sampel penelitian ini adalah kelas XI IPA-2 dan kelas XI IPA- 4.

Penelitian ini menggunakan dua kelas yaitu kelas XI IPA-2 sebagai kelas eksperimen dan kelas XI IPA-4 sebagai kelas kontrol. Kedua kelas tersebut diberi pretest sebelum diberi perlakuan model atau pendekatan pembelajaran, untuk mengetahui kemampuan awal kedua kelas. Dari nilai pretest diketahui bahwa nilai kedua kelas menunjukkan bahwa kedua kelas memiliki kemampuan yang sama sehingga kedua kelas dapat diberi perlakuan model atau pendekatan pembelajaran.

Hasil penelitian menunjukkan bahwa terdapat pengaruh model pendekatan Open Ended Problems terhadap kemampuan berpikir kreatif matematika siswa pada materi peluang di kelas XI SMA Negeri 1 Rantau Utara dimana hasil uji nilai posttest kedua kelas dengan menggunakan uji perbedaan rata- rata Uji Independent Sampel T Test menunjukkan hasil signifikan yaitu nilai signifikan sebesar 0.036 lebih kecil daripada taraf signifikan sebesar 0.05 maka $\mathrm{H}_{\circ}$ ditolak dan $\mathrm{H}_{\mathrm{a}}$ diterima. Serta pada hasil uji t juga diperoleh nilai thitung sebesar 2.224 dan tabel sebesar 1.683, maka $2.224>1.683$, sehingga dalam hal ini dapat ditinjau bahwa terdapat pengaruh pendekatan Open Ended Problems terhadap kemampuan berpikir kreatif siswa.

Pada penelitian Novita Sari Ritonga (2016) yang berjudul "Pengaruh Model Pembelajaran Open Ended Terhadap Hasil Belajar Siswa Pada Materi Sistem Persamaan Linear Dua Variabel Di Kelas X SMA N 1 Silangkitang Tahun Pembelajaran 2015/2016". Berdasarkan analisis data tes, rata-rata skor siswa pada kelas eksperimen adalah 77,94 sedangkan rata-rata skor yang diperoleh pada kelas control adalah 73,97. Dan hasil dari thitung $(2,450)>$ tabel $(1,671)$, maka $\mathrm{H}_{0}$ ditolak dan $\mathrm{H}_{\mathrm{a}}$ diterima, artinya terdapat pengaruh Pembelajaran 
Open Ended Terhadap Hasil Belajar Siswa. Maka, dalam hal ini mendukung penelitian ini dimana hasil penelitian menunjukkan bahwa pembelajaran dengan pendekatan Open Ended Problems kelas eksperimen lebih baik dari kelas kontrol sehingga dalam hal ini dapat ditinjau bahwa terdapat pengaruh pendekatan Open Ended Problems terhadap kemapuan berpikir kreatif matematika siswa.

Berdasarkan hasil analisis deskriptif, diketahui bahwa rata-rata nilai posttest kelas XI-IPA2 (pendekatan Open Ended Problems) adalah 75.75 dan kelas XI-IPA4 (model pembelajaran konvensional) adalah 71.50. Hal tesebut menunjukkan bahwa rata-rata nilai posttest kelas XI-IPA2 lebih baik daripada kelas XI-IPA4, perbedaan rata-rata nilai kedua kelas yaitu 4.25. Artinya pencapaian kemampuan berpikir kreatif matematika siswa kelas XI-IPA2 lebih baik daripada siswa kelas XI-IPA 4.

Dalam proses pembelajaran terdapat model serta pendekatan Pembelajaran yang mempengaruhi pengembangan kemampuan berpikir kreatif matematika siswa dalam belajar matematika di kelas. Berdasarkan hasil proses jawaban siswa yang telah dilakukan dengan menggunakan pendekatan Open Ended Problems terlihat bahwa proses jawaban siswa setelah diberi perlakuan pendekatan Open Ended Problems lebih baik dimana siswa sudah lebih banyak yang menjawab soal dengan jelas, lengkap dan benar sebanyak $87 \%$ jika dibandingkan dengan proses jawaban sebelum diberi perlakuan, ini berarti terdapat pengaruh terhadap kemampuan berpikir kreatif matematika siswa dalam memahami dan menyelesaikan soal, siswa lebih aktif, lebih kompetitif, percaya diri, serta dapat bekerja sama dalam belajar kelompok dan mampu menuangkan pemikiran kreatif matematisnya (kemampuan berpikir kreatif matematika lebih tinggi atau meningkat). Dan hasil observasi menunjukkan bawha dalam pembelajaran menggunakan Pendekatan Open Ended Problems termasuk dalam kategori baik (B) dengan skor $82 \%$.

\section{Kesimpulan}

Terdapat pengaruh penggunaan pendekatan Open Ended Problems terhadap kemampuan berpikir kreatif matematika siswa pada materi peluang di kelas XI SMA Negeri 1 Rantau Utara. Hal ini dapat dibuktikan dari nilai rata-rata kelas eksperimen yang diajarkan dengan pendekatan Open Ended Problems lebih tinggi dari nilai rata-rata kelas kontrol yang diajar dengan metode pembelajaran konvensional $(75.75>71.50)$. Demikian juga berdasarkan hasil perhitungan uji Independent $T$ Test diperoleh nilai Sig. (2-tailed) sebesar 0,036. Nilai Sig. (2-tailed) < 0,05 dimana $\mathrm{H}_{0}$ ditolak dan $\mathrm{H}_{a}$ diterima. Jadi dapat disimpulkan bahwa terdapat pengaruh Pendekatan Open Ended Problems terhadap kemampuan berpikir kreatif matematika siswa.

Berdasarkan hasil dari proses jawaban siswa kelas eksperimen dengan menggunakan pendekatan Open Ended Problems dinyatakan bahwa hasil proses jawaban siswa yang lebih bagus dan lebih baik adalah saat posttest karena hasil dari proses jawaban siswa pada saat posttest lebih jelas, lengkap dan benar.

\section{Daftar Pustaka}

[1] Arikunto, Suharsimi. 2010. "Prosedur Penelitian Suatu Pendekatan Praktik".Jakarta: Rineka Cipta.

[2] Marhami. 2015. Membangun Kemampuan Berpikir Kreatif Dan Komunikasi Matematis Melalui Pembelajaran Problem Based Learning. ed Marsigit, dkk., 149-154. Yogyakarta: Universitas Negeri Yogyakarta. 